\title{
THE JAGIELLONIANS AND THE STARS: DYNASTY-SPONSORED ASTROLOGY IN THE FIFTEENTH CENTURY
}

\section{S. C. ROWELL}

\begin{abstract}
Mediaeval scholars attempted to fit received data and information from empirical observation into a pre-ordained model of the universe. Astrology was, and in many cases still is, a form of applied astronomy held by its adherents to be verifiable by events, that is, history. Drawing connections between celestial coincidences and events known to have happened under such circumstances in the past seemed to offer a possibility for predicting types of occurrence which might take place given a similar stellar conjunction in the future. In their turn some historians, especially those with university connections, subsequently seem to have used astrological records annotated with details of actual events as a source of information for their own work and were able to present, where relevant (in their view), a star-told causation of events. The importance of astrology at royal courts in England, France and Italy has been a subject of special study for a considerable time but the largest centre for astrological study in the fifteenth-century was the University of Cracow. The use of astrology at Jagiellonian courts in the fifteenth century is examined here with reference to the use of such data by court historians such as Jan Dtugosz and Bernard Wapowski.
\end{abstract}

It is clear that the main aim of scholarship in the Middle Ages was to collect, collate, preserve and interpret all types of data ranging from inherited pagan philosophy to revealed theological texts, whilst making empirical observations of the symbolic handbook of Nature and human experience. Every piece of information was presumed to fit a pre-ordained general model of the universe. ${ }^{1}$ One important tool for understanding the symbolic significance of data amassed from empirical observation was astrology, an area of learning closer in today's terms to the U.S. National Aeronautics and Space Administration than the entertainment pages of a daily emission

1 C. S. Lewis, The discarded image. An introduction to medieval and renaissance literature (Cambridge, 1962), pp. 216-23; on astrology in particular, pp. 102-109. 
from la presse jaune. Astrology was, and in many cases still is, a form of applied astronomy held by its adherents to be verifiable by events, that is, history. Drawing connections between celestial coincidences and events known to have happened under such circumstances in the past seemed to offer a possibility for predicting types of occurrence which might take place given a similar stellar conjunction in the future. ${ }^{2}$ In their turn some historians, especially those with university connections, subsequently seem to have used astrological records annotated with details of actual events as a source of information for their own work and were able to present, where relevant (in their view), a star-told causation of events. The importance of astrology at royal courts in England, France and Italy has been a subject of special study for a considerable time. ${ }^{3}$ Much work has been done too on the scientific achievements of the Polish school of astrology and astronomy with which Nicholas Copernicus was closely associated and which in the fifteenth century was one of the major centres of astrological-astronomical learning in Europe. Indeed one of the earliest western manuscripts in Poland, a tenth-century prayer book and psalter which once belonged to Duchess Gertruda (c.1025-1108), sister of Casimir I [Odnowiciel] and wife of Grand Duke Izyaslav of Kiev, includes instructions on forming a meteorological forecast for the whole year. ${ }^{4}$ From the middle to the end of the fifteenth century the Jagiellonian University

2 Roger Bacon, Opus maius pars 4: The 'Opus maius' of Roger Bacon, ed. H. Bridges, I (Oxford, 1897), p. 389 cited by L. A. Smoller, History, prophecy and the stars. The Christian astrology of Pierre d'Ailly, 1350-1420 (PrincetonNew Jersey, 1994), pp. 79-80 and quoted ibid p.181, n. 124.

${ }^{3}$ H. Carey, Courting disaster. Astrology at the English court and university in the later Middle Ages (New York-Oxford, 1992); J. D. North, Horoscopes and History [= Warburg Institute, Surveys and texts, 13] (London, 1986); A. Grafton, Cardano's Cosmos. The Worlds and works of a Renaissance astrologer (Cambridge MA-London, 1999), esp. pp. 109-26.

${ }^{4}$ Much important work has been done in Cracow in recent years by M. Markowski, M. H. Malewicz and G. Rosińska, to name but a few historians of science - see references in notes below for signposts to relevant literature; a brief summary is given in R. Palacz, Filozofia polska XV wieku (Warsaw, 1972), pp. 203-207, 217-226 and R. Bugaj, Nauki tajemne $w$ Polsce $w$ dobie odrodzenia (Wrocław-Warsaw-Cracow-Gdańsk, 1976), pp. 88-99; on Gertruda see B. Kürbis, 'O inspiracji okultystycznej w średniowiecznej wizji dziejów', Świadomość historyczna Polaków. Problemy i metody badawcze, ed. J. Topolski (Łódż, 1983), pp. 77-79 and plate 1. A general survey of astrology in Hungary including royal nativitates and medical applications is given in Á. Jobst, Gyógytó csillagokí (Budapest, 2000), esp. pp.11-19, 44-59. 
in Cracow was the only European centre of learning to maintain separate chairs of astronomy and astrology. ${ }^{5}$ The Polish metropolis was famed beyond the borders of the kingdom for being 'conjectoribus et astrologis ... referta'. ${ }^{6}$

Sponsorship of astrology is a feature of the Jagiellonian courts of central Europe (including both Bohemia and Hungary) and it is to the use and appeal of astrology in Poland and Lithuania in the fifteenth century that our attention will be paid in this article. We will note briefly the support granted to astronomers at Jagiellonian courts, the relationship between astrology and history, astrology and historians and the extension of astrological science to the Grand Duchy of Lithuania by the early sixteenth century.

First of all it should be understood that astrology was not held universally to be an example of diabolical trumpery (as it is now in Catholic catechisms), despite the disapproval it earned from certain fathers of the Church such as St Augustine. In the fifteenth century for many people it was 'proper science', which often meant the same as astronomy and involved detailed observation of the skies, the calculation of calendars (predicting in advance the date of Easter, to give its most common and necessary use) and time, although it could be misused by knaves and fools. It was also used to establish celestial positions which were regarded by serious scholars as being significant for their influence human life, for birth, death, sickness (not just what we still call 'influenza'), personal character and so forth. It was when astrologers stepped over the boundary between general descriptions of the likelihood of 'atmosphere' in 'iudicia' applicable generally to places, nations and such like, to predicting specific predetermined events that they could face condemnation. Cardinal Pierre d'Ailly (1350-1420), who attempted to set down a world chronology from Creation to the Second Coming based on astrological calculations, declared, and

5 A. Birkenmajer, Etudes d'histoire des sciences en Pologne [= Studia Coperniciana 4] (Wrocław-Warsaw-Cracow-Gdańsk, 1972), p. 479. This volume contains translations of work published by Aleksander Birkenmajer in various learned journals in the inter-war period.

${ }^{6}$ Antonius de Bonfinis, Rerum ungaricarum decades quattuor cum dimidia (Frankfurt, 1581) p. 715 sub anno 1491. A similar view was held by the Nuremberg chronicler, Schedel in 1493 (Die Schedelsche Weltkronik. Nachdruck der deutschen Ausgabe von 1493, ed. R. Poertner [Dortmund, 1978], fo. 264-265r). The claim that astrology was less popular in Poland than in western Europe made in the nineteenth century is over-optimistic - Z. Gloger, Encyklopedia staropolska ilustrowana I (Warsaw, 1989, photo repr. of 1900 ed.), pp. 82-84. 
the Polish astrologer Jan of Głogow agreed with him, that astrology was not out of keeping with Christianity per se or bad, even though some bad astrologers might abuse it by mixing it with 'magic'? Therefore, the use of astrology at court was not of itself sinful. Jogaila, whom one would expect to be wary of becoming involved with theologically dubious persons, doctrine and learning (he was regarded by his supporters as christianissimus but by his enemies as a retrograde and devious pagan), gave refuge to an astronomer who had been chased out of Bohemia and who would in time be tried (and acquitted) for magic, or rather doctrinal heresy in Poland. ${ }^{8}$ The good ruler might have his learned star-gazer, medico and

7 M. H. Malewicz, 'Ioannis de Glogovia "Persuasio brevis quomodo astrologiae studium religioni christianae non est adversum", Studia Mediewistyczne 24 (1985), pp. 153-75; on the reception of d'Ailly's work in Poland, see ibid, pp. 156-62 and in general: Smoller, History, passim; on the diverse attitudes of mediaeval Polish scholars to astrology (Stanisław of Skarbomierz and Benedykt Hesse were suspicious of the art to say the least) see M. Markowski, 'Stanowisko średniowiecznych przedstawicieli uniwersytetu krakowskiego wobec astrologii', Biuletyn Biblioteki Jagiellońskiej 49 (1999), pp. 95-102.

${ }^{8}$ Henry the Bohemian: S. Wielgus, "Consilia" de Stanislas de Scarbimiria contre l'astrologue Henri Bohemus (édition critique)', Studia mediewistyczne 25:1 (1988), pp. 145-92. Henry was connected with Jogaila's court from around 1423 and attended the births of Queen Sofia's three sons. He was active until at least 1440 despite having been found guilty of doctrinal error in 1429 - ibid, pp. 145, 149. For further literature, see Wielgus's notes. Sub anno 1427 Długosz records the prophecies made by Henry for Princes Władysław (to rule many kingdoms and principalities - in effect the same prediction as that for Casimir IV's eldest son, also called Władysław - J. Długosz, Historiae polonicae V (lib. xii), ed. A. Przezdziecki (Cracow,1878), p. 221 [henceforth: Długosz, Hist. V]; a chart is provided in Cracow, Biblioteka Jagiellońska [BJ] ms. 1963 fos. 256r-v, dated 1506 from treatise arguing that the sun is favourable in the twelfth house for daytime births and the moon for those born at night - G. Rosińska, Scientific writings and astronomical tables in Cracow (XIVth-XVth centuries) [= Studia Coperniciana, 22] (Wrocław, 1984), No. 1146. Predictions existed for Casimir (that he would not live long) and Casimir [IV] Andrew (that he would live longest but his reign would be ill-fated since the prince was born under a bad star) - J. Długosz, Roczniki czyli kroniki sławnego Królestwa Polskiego, księga jedenasta, 1413-1430, ed. D. Turkowska et al. (Warsaw, 1985) pp. 241-42. Horoscopes were indeed drawn up for the sons of Sofia and Jogaila - see below pp. 39-41. The varied opinions of Jogaila's Christianity are illustrated well in K. Biedrowska-Ochmańska and J. Ochmański, Władystaw Jagiełto w opiniach swoich współczesnych. Próba charakterystyki jego osobowości (Poznań, 1987), pp. 48-51; cf. the view held by supporters of the Teutonic Order: T. Tyc, 'Inwektywa na Litwinów i Polaków z XV w.', Ateneum Wileńskie, IV:13 (1927), pp. 459-62; or the infamous Satira penned by Johannes Falkenberg: H. Boockmann, Johannes Falkenberg, der Deutsche Orden und die polnische Politik. Untersuchungen zur politischen Theorie des späteren Mittelalters (Göttingen, 1975). 
confidant whilst the tyrant would be accused of patronizing soothsayers and witches. ${ }^{9}$

Casimir III (the Great) (1333-1370) had a doctor-astrologer and this combination of professions is common, as was the case with the renowned Renaissance schoolman and historian Maciej of Miechow (Miechowita, c.1457-1523), for the stars predicted when it would be propitious to perform certain medical operations. ${ }^{10}$ Astrologers do not feature in Stanisław Ożóg's study of intellectuals in the service of the Polish Crown in the fourteenth century, but this may be because the author concentrates mainly on the development of political ideology. ${ }^{11}$ Queen Jadwiga and King Jogaila had an astrologer who predicted the birth of a son (sic) in 1399. ${ }^{12}$ This tradition continued in the days of Jogaila's fourth wife, Sophia; in Jogaila's case we learn of them from periods when his wife was pregnant, a good time to curry favour with a dynast. ${ }^{13}$ In Casimir IV's day the court was served by university specialists such as the Silesian physician Piotr Gaszowiec, who drew up astronomical tables

${ }^{9}$ We have in mind here the accusations laid against Grand Duke Žygimantas Kęstutaitis as an explanation and quasi-justification of his murder by Lithuanian noblemen on Palm Sunday 1440 - Długosz, Annales et cronicae... Liber undecimus et liber duodecimus 1431-1444, ed. D. Turkowska et al. (Warsaw, 2001), pp. 216-18. For context, see S. C. Rowell, 'Bears and traitors, or: political tensions in the Grand Duchy ca 1440-1481', Lithuanian Historical Stucies 2 (1997), pp. 28-55 and more recently, J. Nikodem, 'Przyczyny zamordowania Zygmunta Kiejstutowicza', Białoruskie zeszyty historyczne, 17 (2002), pp. 5-33. The grand master of the Teutonic Order Heinrich von Plauen, who was deposed in 1413, was accused of having taken the advice of soothsayers and astrologers ['sternsehern und wyssagern' who counselled war, according to the Continuator of Johann von Posilge's chronicle, Scriptores rerum prussicarum III (Leipzig, 1866, repr. Frankfurt aM, 1965), pp. 334-37, here 334] rather than that of his brother officers (Długosz gives a political motivation - Roczniki czyli kroniki, p. 25). Bishop Conrad of Wrocław condemned those who 'videt in astrolabo futura' to two years' penance in his diocesan statutes of 1446.

${ }^{10}$ In general on the connection between medicine and astrology, see S. J. Tester, A History of western astrology (Woodbridge, 1987), pp. 186-89.

${ }^{11}$ S. Ożóg, Intelektualiści w stużbie Królestwa Polskiego w latach 13061382 [= Uniwersytet Jagielloński, Rozprawy habilitacyjne, 307] (Cracow, 1995), pp. 91-2: Casimir the Great's physicians, confessors and chaplains; for those serving Louis the Great and Queen Elżbieta, see ibid. p. 104.

${ }^{12}$ BJ 805 fo. 407v-408r, Rosińska, Scientific writings, No. 677; a convenient, albeit painfully reduced reproduction is given in Kultura Polski średniowiecznej $X I V-X V$ w., ed. B. Geremek (Warsaw, 1997), p. 749, ill. 546. The aim of the collector of this horoscope seems to be to illustrate how a mistaken calculation could lead to predictions for a male rather than a female child.

${ }^{13}$ See above n. 8. 
calculated on the meridian at Cracow, ${ }^{14}$ Marcin Król and Jan of Głogow. Marcin Bylica of Olkusz served both Casimir IV and the Hungarian king-pretender Matyas Corvinus $;{ }^{15}$ Cardinal Frederick, for whose ordination a chart was compiled, sent Wojciech of Brudzewo to serve his brother Grand Duke Alexander (see below).

A selection of astrological tables, such as those in Jagiellonian Library manuscripts 3225 or 3227 in Cracow, also seems to throw light inadvertently on the views (actually held or conveniently expressed) of the person who drew them up. The most blatant example is provided by tables for George Podiebrady, king of Bohemia and King Matyas Corvin of Hungary (and Bohemia) which were included in a Lwów manuscript as quoted by L. Birkenmajer. One table gives 'revolutio anni mundi precedens coronationem Georgii de Podzebrad qui se pro Bohemorum rege gerit' where George is 'acting king of the Bohemians', while another gives the birth of 'serenissimi domini Mathie Hungarie, Bohemie etc regis'. ${ }^{16}$ To give an example of the heterodox views of Jagiellonian rights as heirs to the Polish throne (as opposed to being solely the elect of the Polish noble elite) we might cite the nativitas (birth horoscope) for a child to be born to Jogaila and Jadwiga in 1399 which is preserved in a copy in a Cracow manuscript and speaks of 'estimata conceptio domini eredis filii', the main point for us to note here being not that the child turned out to be a girl but that it was regarded as an heir (to the Polish Crown, a political subject whose legitimacy was disputed strongly by certain factions of the Polish nobility), while a birth chart for the daughter as given in the same manuscript does not refer to her being an heir at all. ${ }^{17}$ The presence of one word, eres, may seem to be of very slight significance.

${ }^{14}$ A. Birkenmajer, Etudes, pp. 458-59, 471-72. Gaszowiec brought Italian astronomical tables to Poland.

${ }^{15}$ Marcin z Zórawic called Rex (in Polish “Król”) - A. Birkenmajer, Etudes, pp. 457-58, 470 and L. Birkenmajer, Marcin Bylica z Olkusza oraz narzedzie astronomiczne, które zapisat Uniwersytetowi Jagiellońskiemu w roku 1493 [= Rozprawy Akademii Umiejętności, wyd. Matematyczno-przyrodnicznego, Serya 2 vol. 5 (1893), pp. 21-27. Głogow - see above n. 7 and below n. 28. Marcin Bylica L. Birkenmajer, Marcin Bylica and M. Markowski, 'Martin Bylica aus Olkusz als Vermittler zwischen Johannes Regiomontanus und der Krakauer astronomischen Schule in der vorkopernikanischen Zeit', Studia mediewistyczne 26:2 (1989), pp. 125-32.

16 L. Birkenmajer, Marcin Bylica, p. 134 n.158 citing ms Biblioteka Ossolineum, Lwów 764 fos 437 and 43.

${ }^{17}$ Rosińska, Scientific writings, No. 677 [Ms. BJ 805 fo. 407v-408]; cf. ibid No. 719 [fo. 408r]. At least the child's conception on September 16 and birth on June 22 indicates normal gestation! 
However, taken together with other ephemeral texts which speak of the descendants of Jogaila as heirs to the Polish throne, they help balance out the view prevalent in historical studies that the elective nature of the Polish Crown was unchallenged in the early fifteenth century. ${ }^{18}$ That these 'model horoscopes' propagate a particular view of the royal family is surely important if they were used as teaching materials - the eldest son of the Jagiellonian king of Poland seems pre-ordained by the stars, if not by the unwritten political 'constitution', to rule. These collections of horoscopes from 'real life' form a complement to (printed) handbooks of theoretical horoscopes such as that whose illustrations have been analysed recently by Ewa Snieżyńska-Stolor and Joanna Komorowska. ${ }^{19}$ 'Textbooks' can be a very potent source of information and disinformation, as modern examples bear sad witness.

A general iudicium for 1451 is preserved in ms. BJ 764 pp. 1-27 and it seems to be the earliest surviving Polish example of the genre. L. Birkenmajer attributes it indirectly to Marcin Bylica ${ }^{20}$. Intermingled with the astrological comments is a copy of an address by Rytwiański to Pope Pius II asking for the appointment of Bishop Jan Gruszczyński of Włocławek to the see of Cracow after the death of Bishop Tomasz Strzepiński. ${ }^{21}$ The prophecy gives monthly weather forecasts, the threat of pestilence and war, ${ }^{22}$ accounts of the state of the major religions, Christianity and Islam, according to the methods of Abu Ma'shar (Albumazar) ${ }^{23}$ and pays particular attention to the realms of Poland and Hungary.

War is predicted 'in regionibus sub thauro ut Polonia' and 'omnes provincie circa littora maris', a fair enough bet for a year

${ }^{18}$ Here we have in mind the dual (hereditary-elective) explanation of Polish political history offered in Czartoryski Ms 1399 by Długosz and another commentator: S. C. Rowell, 'Fifteenth-century Poland-Lithuania in the light of an anonymous Kraków notebook', Quaestiones medii aevi novae 8 (2003) in press.

${ }^{19}$ E. Snieżyńska-Stolor and J. Komorowska, Ikonografia astrologiczna $w$ średniowieczu. Stopnie znaków zodiaku (Cracow, 2002).

${ }^{20}$ L. Birkenmajer, Marcin Bylica, p. 24. At the end of the forecast there is a text mentioning one $\mathrm{M}$ de $\mathrm{B}$, decretorum doctor and later Nicolaus de Bylica BJ 764 p. 27. This text mentions legates of Sixtus IV, cardinal mark of St Mark and Bishop Rudolph of Wrocław.

${ }^{21}$ BJ 764 pp. 13-16. For further documentation of this episcopal controversy see Bullarium Poloniae litteras apostolicas aliaque monumenta Poloniae Vaticana continens VI, ed. I. Sułkowska-Kuraś, S. Kuraś et al. (Rome-Lublin, 1998) and Długosz, Historia V, pp. 309-311 sub anno 1460.

22 BJ 764 pp.11-12.

${ }^{23}$ Arab author of Isagoge Minor - see Tester, A History, pp. 147-8; here p. 10 of BJ 764 . 
when Casimir was still in conflict with the Tatars in Lithuania and their protégé Mykolas, son of Žygimantas Kęstutaitis. ${ }^{24}$ The (as yet unwed) Polish king is expected to be successful in love and war. ${ }^{25}$ The astrologer also mentions the prospects for the Pope, the Emperor, the king of France and a whole series of secular rulers before moving on to discuss the prospects of people of various professions. Merchants are in for a hard time, especially those in trade with England. ${ }^{26}$ Could it be that the countries selected for mention in the horoscope reflect those with which the Polish court had most interest in maintaining contact, or simply that the astrologer borrowed his data from western sources? It is noticeable that Rus' is absent from this list.

What the astrologer says about parts of Lithuania, a place he locates with Denmark, Norway and Sweden under the influence of Aquarius, while being generally correct in terms of climate and terrain, could have been culled from commonplaces expressed by Bartholomew Anglicus and other authors. The country has many water sources in spring, autumn and winter but has dry summers. ${ }^{27}$

BJ 764 presents a good and early example of one type of astrological sub-genre, the iudicium, drawn up on the basis of general interpretation of the position of stars calculated in advance, a type of 'Old Moore's Almanack'. Such calculations could be made for several years at a time. The best known examples of this type of text from Cracow in the second half of the fifteenth century come from the pens of Jan of Glogow and Johannes Regiomontanus. ${ }^{28}$ The latter produced and had printed a Kalendarium et ephemerides $X V$ annorum. It is a calendar for 1475-1531 and may have been a source for Frantisek Skorina's Paschalia, one of the first books to be printed in the Grand Duchy of Lithuania with calculations of moveable feasts for the years $1523-1543 .{ }^{29}$ Skorina was a physician

${ }^{24}$ Wars under the sign of taurus - p. 18; war with Tatars - L. Kolankowski, Dzieje Wielkiego Księstwa Litewskiego za Jagiellonów, i: 1377-1499 (Warsaw,1930), pp. 264-74.

25 'rex Polonie in domo Veneris, victor in bellis': BJ 764 p.12 and 17.

${ }^{26} \mathrm{Ibid}, 17$ for kings of Hungary, Aragon, Castile, the Doge of Venice, Rome, the Turks and Tatars, Florence; for prelates, doctors, merchants.

${ }^{27}$ BJ 764 p. 19.

${ }^{28}$ Głogow - M. Markowski, 'Repertorium bio-bibliographicum astronomorum cracoviensium medii aevi. Ioannes Schelling de Glogovia', Studia mediewistyczne 26:3 (1990), pp. 107-111.

${ }^{29}$ Regiomontanus - see Markowski, 'Martin Bylica'; Frantisek Skorina L. Vladimirovas, Pranciškus Skorina - Vilniaus spaudos pradininkas (Vilnius, 1956), 24 discusses the Malaia podrozhnaia knizhka which is reprinted in Frantsysk 
and had undergone training in Cracow and Prague and hence his interest in astronomy and astrology is understandable.

Astrology and the Historians In an interesting article on potential sources available to Jan Długosz when the Cracow canon was compiling his encyclopedic history of the kingdom of Poland Sławomir Gawlas considers almanac texts which were (or may have been) available to the historian and his patron, Bishop Zbigniew Oleśnicki. He suggests that Długosz may have used astrological calendars on which certain historical events were recorded and draws later parallels with the work of the historian-physician-astrologer Maciej of Miechow. ${ }^{30}$ Calendars do survive on which royal secretaries and other officials and personages did record what events they had witnessed or learned about from others and some of these ephemera have been in scholarly circulation for over a century. ${ }^{31}$ Similar use of almanacs for recording actual events can be found in other countries. One example is provided by the Buda cleric Janos Kakas who recorded events from his life, including the burial of Alexander in Vilnius and the accession of Sigismund the Elder, on a printed almanac that he purchased during his years of study in Cracow. ${ }^{32}$ We know that historians had access to birth charts, as Bernard Wapowski's autograph note on folio 1 of the Jagiellonian Library's manuscript 3225 bears convenient witness. ${ }^{33}$ We also know that Długosz made reference to heavenly portents in his chronicle, as did other annalists. ${ }^{34}$

Skaryna, Tvory: pradmovy, skazanni, pasliaslui, akafisty, paskhalia, ed. A. F. Korshunov and V. A. Chamiarytskiy (Minsk,1990), pp. 94-102, 180-83; G. Ia. Golenchenko, 'Astronomicheskie svedenia v izdaniiakh Frantsiska Skoriny', Knygotyra 7 (14) (1979), pp. 54-9.

30 S. Gawlas, 'Astrolog przyjacielem historyka? Diariusz Zbigniewa Oleśnickiego w genezie Roczników Jana Długosza', Kultura średniowieczna i staropolska. Studia ofiarowane Aleksandrowi Gieysztorowi w pięćdziesięciolecie pracy naukowej, ed. D. Gawinowa, S. Gawlas et al. (Warsaw, 1991), pp. 455-69.

${ }^{31}$ Erazm Ciołek for example - L. Birkenmajer, 'Zapiski historyczne wsród starych almanaców Biblioteki Jagiellonskiej', $K W 16$ (1902), pp. 445-57.

${ }^{32}$ A. Kubinyi, 'Budai Kakos János és történeti feljegyzési', Föpapok, egyházi intézmények és vallásosság a középkori Magyarországon (Budapest, 1999), pp. 193-211, esp. 193-8 and 207-11. Similar ephemeral data is present on Erazm Ciołek's almanac - L. Birkenmajer, 'Zapiski', pp. 454-55. These are more like the equivalent of pocket diaries than serious astrological texts.

${ }^{33}$ See below pp. 39-41.

${ }^{34}$ U. Borkowska 'Prodigia i myślenie zracjonalizowane w "Rocznikach" Jana Długosza', Kultura elitarna a kultura masowa w Polsce póżnego średniowiecza, ed. B. Geremek (Wrocław-Warsaw-Cracow-Gdańsk, 1978), pp. 231-41; M. H. Malewicz, 
Długosz would not be Długosz if his attitude to such portents were not both expedient and sceptical. He cites heavenly disapproval on certain occasions while exhibiting his own disapproval of pro-royal astrologers on others. It is unclear whether courtier suspicions of astrologers were based on disdain for their art or fear of their intimate association with the ruler, as in the case of Oleśnicki's pique at private interviews between Jogaila and the Bohemian astrologer Cristianus' envoy in $1433 .{ }^{35}$

Długosz deliberately surrounds Casimir Jagiellończyk with bad signs. He claims that Jogaila's court astrologer, Henry the Bohemian, predicted that during Casimir's reign many bad things would happen. ${ }^{36} \mathrm{He}$ says that astrologers linked bad events connected with Casimir's coronation with his bad stars ${ }^{37}$ and this view was vindicated by misfortunes that took place in the young king's presence, such as the fire of Poznań in 1447. Like some malignant schoolboy he darkens the skies around Casimir further by noting how conspicuously happy were the signs surrounding his brother Władysław and eldest son (of the same name). Długosz is not consistent in his reference to horoscopes and 'exact' times of royal births. Astrologers are mentioned in connection with the birth of Casimir's eldest son but not for any of the others. Some births are given to the day, some to the hour of the clock and others according to the canonical hours. ${ }^{38}$ Astrology would appear to provide good cover for the chronicler to indicate a king of misfortunes without personally attacking the monarch. Wiszniewski notes that Casimir's rejection of the Bohemian crown in 1438 was the result of advice from Oleśnicki but that it was attributed by Cracovian astrologers

Zjawiska przyrodnicze $w$ relacjach dziejopisarzy polskiego średniowiecza [= Monografie z dziejów nauki i techniki cxxiii (Wrocław-Warsaw-Cracow-Gdańsk, 1980), pp. 27-48.

35 Długosz, Annales seu cronicae, p. 168. A Cristianus [de Prachatice?] produced a longitudinal verification in 1423 that survives in BJ 573 p. 377, a manuscript of circa 1457: Rosińska, Scientific writings, No. 168, p. 46. Is he the same man whose envoy met Jogaila in 1433, according to Długosz?

${ }^{36}$ J. Długosz, Historiae polonicae IV, ed. A. Przezdziecki (Cracow, 1878), 349; Henryk Czech - PSB IX, 419 f.

${ }^{37}$ Długosz, Hist. V, pp. 31, 33.

${ }^{38}$ Władysław - Długosz, Hist. V, p. 221; clock hours for John Albert (p. 301, roughly coinciding with the horoscope in Rosińska, Scientific writings, No. 1245), Zofia (p. 389), Frederick (p. 503); canonical hours for Jadwiga (p. 254), Anna (p. 639); dawn (Casimir, p. 275), midday (Elisabeth II, p. 568), midnight (Sigismund, p. 474); day - Alexander, p. 319, Elisabeth I, p. 413, Barbara, p. 675. 
to the prince's horoscope. Długosz mentions only Oleśnicki's role in the affair and Wiszniewski does not provide a more precise reference. ${ }^{39}$ Surviving horoscopes do not appear to confirm the chronicler's gloom-laden point of view completely (see below).

Astrology gives an impression of being both mathematically precise and interpretationally vague. If Casimir was doomed by the stars at birth and his coronation, the victorious peace of Torun which put an end to the Thirteen Years' War with the Teutonic Order in 1466 is attributed by Długosz not to the king's skill but to a fortunate conjunction of the stars; the defeat at Choynice in 1454 is blamed on Casimir's sin (as understood in a dream by a visiting cleric) by Długosz but on the stars by the astrologer of BJ 3225. However, Długosz does mention that in 1454 not only monks and nuns but also 'astrorum peritis' advised against war. ${ }^{40}$ The seventeenth-century university historian Radymiński may have taken this manuscript as a source for his claim that astrologers warned the king against battle in $1454 .{ }^{41}$

Precision can fit the requirements of interpretation rather than simply plain data and it would be naive to think that the presence of astrological dating in Lithuanian chronicle accounts, such as the record of Sigismund the Elder's death in 1548, or that of Sigismund Augustus's wife Elisabeth in 1545 necessarily reflects a greater awareness of detail in daily life or a 'renaissance' approach to recording time. ${ }^{42}$ It is part and parcel of a wider 'mediaeval' culture. As Hajdukiewicz noted, astrologers give dates 'with an amazing but suspicious pedantry down to the hour and minutes'. ${ }^{43}$ These

${ }^{39}$ M. Wiszniewski, Historya literatury polskiej, IV (Cracow, 1842), p. 154; Długosz, Annales seu cronicae, pp. 179-81.

${ }^{40}$ Długosz links the beginning and happy end of the war with Halley's comet 'ex cuius apparitione ... augurabantur, maioresque effectus prodigium Cometen in Prussia et Lithuania et aliquibus partibus Maioris Poloniae' - Długosz, Hist. V, p. 226; Choynice - pp. 191-2 and below n. 77; 'multa praeterea nuntiabantur signa futurae in regem cladis, tam a religiosis viris et feminis, quam ab astrorum peritis' - Długosz, Hist. V, p. 184.

${ }^{41}$ Wiszniewski, Historya, IV, p. 157, citing Radymiński’s 1634 opus.

${ }^{42}$ Polnoe sobranie russkikh letopisei, XXXV, pp. 172, 238 [Evreinovskaia]; for Elisabeth ibid, 213 [Rumiantsevskaia]. The Evreinovskaia chronicle does not give Elisabeth's death, but does note that of Sigismund. Other obits do not mention an exact time of death. Are some people simply more important than others or did the sources for some obits include astrological notes? The answers to such questions are impossible to give.

43 'z zadziwająca, ale podejrzaną pedanterią godziny i minuty': Hajdukiewicz, Biblioteka Macieja, pp. 131-32. 
exact calculations deduced from celestial observance make an event fit the stars rather than a clock. For example the horoscope for Cardinal Frederick Jagiellończyk on p. 29 of the Almanac for 1501 preserved in Cracow dates Frederick's birth 'precisely' to April 24 1468 at two minutes to midnight when the sun is in the ascendant, the sign of leadership in public life. ${ }^{44}$ In a letter to his brother and fellow astrologer Stanisław, Marcin z Olkusza explains how birth charts were faked in Hungary by changing dates and how Marcin has developed a better system for an accurate horoscope. ${ }^{45}$

The first known example of an astrologer-cum-civil-servant in the Grand Duchy of Lithuania comes from the end of the fifteenth century and has direct connections with the cultural interests of the Jagiellonian family. Wojciech Blar of Brudzewo, the renowned Cracow divine and professor of astronomy was invited by Grand Duke Aleksander to enter his service in Vilnius. ${ }^{46}$

Wojciech was born in Brudzewo (Wielkopolska) in 1445 or early 1446; he studied under Jan of Głogow (among others) at Cracow after 1468. Jan Brozek says that he was a teacher of Copernicus and Bernard Wapowski (the historian) ${ }^{47}$. He worked on paschal tables and movements of the sun for $1481^{48}, 1487^{49}, 1491$, and 1492. ${ }^{50}$ Apart from lecturing (1482-1493) on logic, physics, astronomy and Aristotelian metaphysics, Wojciech also gave lectures in 1490 on Livy's History of Rome Ab urbe condita. Unfortunately these do not survive in manuscript and so we cannot know whether he linked astrology and chronology in his understanding of history (as did Pierre d'Ailly ${ }^{51}$ ). Wojciech was a close friend of Grand Duke - King Casimir's learned Italian-born secretary, Filip Kallimach, and a member of the Cracovian humanist intellectual fellowship known as the 'Sodalitas Vistulana'.

44 J. Dobrzycki, 'Tablice astrologiczne Jana Regiomontana w Krakowie', Studia Mediewistyczne 26 (1988), pp. 69-90, citing BJ 8.

${ }^{45}$ Wiszniewski, Historya iv, pp. 162-4; a treatise on calculating conception dates appears in BJ 3225: Rosińska, Scientific writings, No. 1146.

${ }^{46}$ R. Palacz, 'Wojciech z Brudzewa jako astronom i filozof', Materiaty do historii filozofii średniowiecznej w Polsce 7 (18) (1974), pp. 53-91.

47 Ibid. 64, quoting a marginal note from BJ 560 fo.1.

48 Almanac BJ 579 pp.1-23, Rosińska, Scientific writings, No. 133.

49 BN 7350, Rosińska, Scientific writings, No. 147.

${ }^{50}$ Palacz, 'Wojciech', p. 66.

${ }^{51}$ Smoller, History, pp. 77-84. Palacz, 'Wojciech', 49 attributes these lectures to classical interests inspired by Kallimach. 
In February 1494 he received permission from the University (whose chancellor was Cardinal Frederick) to go to Vilnius for a year to serve as secretary to Alexander of Lithuania; he died in service at the Vilnius court in April 1495. In Vilnius at court and in the cathedral chapter he had acquaintances with whom he had studied a generation earlier, namely Adam of Vilnius and the bishop, Wojciech Tabor. ${ }^{52}$ Marginal notes in a Cracow manuscript tell us that Wojciech became canon in Vilnius cathedral, but Jerzy Ochmański does not list him as a chapter member and he does not appear in any surviving chapter document as a recipient, donor or witness of favours. ${ }^{53} \mathrm{In}$ fact, one begins to doubt whether Wojciech actually took up residence in Vilnius. One of Wojciech's books, Commentum in Theoricas planetarum Georgii Purbachii, was published by Uldarich Scinzenzeler in Milan (November 8, 1494) when the author is thought to have been resident in Vilnius. The Lithuanian bibliographer N. Feigelmanas says that this book reached Wojciech in Vilnius and although this is not entirely impossible, it is not certain. The same publisher produced an expanded edition of this text at the end of March 1495, a short time before Wojciech's death. This book is known to have been in a Vilnius library, although it is not known when it reached Lithuania. Thus it is difficult to provide evidence of Wojciech's personal influence on readership of his works in Lithuania. ${ }^{54}$

52 What is known of Wojciech's life comes mainly from inscriptions in manuscripts which once belonged to him and which he bequeathed to the Divinity Library in the Cracow Faculty of Arts and from University protocols: BJ 1530, fo.1, 3821 [Conclusiones universitatis] sub anno 1494, 1943 fo.1 and 1359 fo.1. These and other texts are given in R. Palacz, 'Wojciech Blar z Brudzewa. Stan badań', Materiały i studia zakładu Historii Filozofii starożytnej $i$ średniowiecznej, Seria A: Materiaty do historii filozofii średniowiecznej $w$ Polsce I (1961), pp. 172-98, esp. 172, 177, 193-4. Adam Jacobi de Kotra alias de Wilno, grand-ducal scribe and canon of Vilnius cathedral: book owner, N. Feigelmanas Lietuvos inkunabulai (Vilnius, 1975), p. 455 No. 144; W. Urban, S. Lūžys, Cracovia Lithuanorum saeculis XIV-XVI. Lietuviu Krokuva XIV-XVI amžiais (Vilnius, 1999), pp. 60, 62, 66, studied in Cracow from 1479; J. Ochmański, Biskupstwo wileńskie w średniowieczu. Ustrój i uposażenie (Poznań, 1972), p. 39; Wojciech Tabor - ibid.

${ }^{53}$ Ochmański, Biskupstwo. At least not in Kodeks Dyplomatyczny Katedry i Diecezji Wileńskiej, I (1387-1507) [KDKDW], ed. J. Fijałek and W. Semkowicz (Cracow, 1932-1948).

${ }^{54}$ Feigelmanas, Lietuvos inkunabulai, p. 434, nos 57 and 58 in the chapter on incunabula known to have been in Lithuania. There is no evidence that 57 ever was in the country; No. 58 was in Vilnius University Library in the early nineteenth century until the university was closed down in 1833 and later transferred to the 
Basic fifteenth-century astrological-astronomical textbooks are known to have been in Lithuania, but there is no exact information as to how or when they reached the country. They include editions of Regiomontanus, Abu Ma'shar, Albuhali. Some of them are bound together with early-sixteenth-century medical tracts. ${ }^{55} \mathrm{~A}$ Venetian edition (1494) of Albert the Great's De Meteoris purchased by one Forsterus Junior in September 1549 and annotated by him seems to have caused no astrological curiosity in its owner or subsequent readers. ${ }^{56}$

The 8 May 1510 list of books that belonged (most probably) to Albrechtas Goštautas [Olbracht Gasztold], chancellor of the Grand Duchy of Lithuania, which is preserved in Lithuanian Metrica Codex 223 (formerly II A/3) fos. 160, 168, 169 (formerly fos. 153, 161, 162 ) and published as referring to the Vilnius library of Grand Duke Sigismund [the Elder] includes an 'Almanach perpetuum' (attributed by Kazimierz Hartleb to Johannes Regiomontanus), but this is probably evidence of practical devotion on Goštautas's part rather than necessarily an interest in astrology. Every good Christian needs a table of moveable feasts. ${ }^{57}$ Library lists, however, may be a misleading source. Sigismund Augustus is famed for his interest in astrology and the 'black arts', but his Vilnius Library contains very few volumes on astronomy or astrology and most of what there was was connected with the former. ${ }^{58}$

Lithuanian interest in astrology is difficult to track down. Early mediaeval Lithuanians seem to have consulted the stars, according to the interpretation made by archaeologists and astronomers such as V. Žulkus and L. Klimka of finds made in Palanga. These remains

Vilnius Observatory. Its present whereabouts are unknown. Feigelmanas clearly overstates his hypothesis that "visai galimas daiktas" these volumes reached Wojciech (or indeed Vilnius) - ibid, pp. 17-18. He follows Michał Wiszniewski's error (Historya IV, pp. 144-5) in dating Wojciech's death to 1497.

${ }^{55}$ Feigelmanas, Lietuvos inkunabulai, p. 169, n.192 (belonged to a Vilnius Franciscan in the eighteenth century); p. 421 No. 5 and pp. 449-50 No. 120.

${ }^{56}$ Vilnius, MAB Central Library I-26e; on Albert's works preserved in libraries of the Lithuanian Republic (not the same as the Grand Duchy of Lithuania) see Feigelmanas, Lietuvos inkunabulai p. 75, nos. 10, 11.

${ }^{57}$ Book list published conveniently in K. Hartleb, Bibljoteka Zygmunta Augusta. Studium z dziejów kultury królewskiego dworu (Lwów, 1928), pp. 135-36. The Lithuanian Metrica is preserved in Moscow. Correct attribution given in K. Jablonskis, ' $1510 \mathrm{~m}$. Albrechto Goštauto biblioteka', Vilniaus valstybinis V. Kapsuko vardo universitetas: Mokslinès bibliotekos metraštis 1958-1959 (Vilnius, 1961), pp. 21-25.

${ }^{58}$ Hartleb, Bibljoteka, pp. 168-69; the only 'astrological' volume is Alfonso of Spain's astronomical tables. Purbachius also features therein. 
are dated by Žulkus to the late fourteenth and early fifteenth century but typically back-dated to an uncertain earlier date. Lithuanian astronomical learning in the fifteenth century was not a thing of the past, although it is unclear whether it had astrological uses. ${ }^{59}$ The interest shown by the Jagiellonians in the science is typical of what we should expect of late-mediaeval and early modern princes. Among Cracow and Prague astrological writings we come across possible Lithuanian links in the fifteenth century but these are very unclear. We find a horoscope for one Joannis Andreas Olechnowicz, ${ }^{60}$ a computus drawn up in Prague by one Matthias Wyl[n?]ensis and a table for John, son of the Duke of Grodno [? - Grodensis]. ${ }^{61}$

Horoscopes provide a map of the sky at birth. They are usually circular and are marked with the twelve signs of the zodiac; they are divided into decans, with a table of the domus with four main points, mark the latitude of the place where the person was born and usually give a table of planetary positions. The birth horoscopes or nativitates were often rectangular in form with triangular 'houses'. According to Jan of Głogow in the third part of his Summa astrologiae these horoscopes reveal details of a person's 'life, death, wealth, morals, friends, enemies and other accidences'. ${ }^{62}$ Another practitioner explains that they illustrate 'quedam valencia ad nativitates experiendas hominum et primo de nativitatibus incompletis Martis ... X ... vir pauper, filiorum multorum, voce parva, vilicus vel paraliticus'. ${ }^{63}$ They offer predictions that a child will survive his early years or endure a good death. ${ }^{64}$ An example

${ }^{59}$ V. Žulkus, 'Birutès kalnas ir gyvenvietè Palangoje', LIM 1985 (Vilnius, 1986), pp. 21-35 and idem, Palangos viduramžiu gyvenvietès [Acta historica universitatis Klaipedensis 6 (1997), pp. 47-54 and L. Klimka, 'Apie astronominę Palangos alko statinio paskirti', LIM 1985, pp. 36-43. Mediaeval Christian accounts of Baltic divination do not refer to use of the stars - R. Mažeika, 'Granting power to enemy gods in the chronicles of the Baltic crusades', Medieval frontiers: concepts and practices, ed. D. Abulafia and N. Berend (Aldershot, 2002), pp. 164-66.

${ }^{60}$ There is a Lithuanian Andreas Olechnowicz, the grand duke's 'tenutarius in Oszsza', active in Vilnius in the late fifteenth century - KDKDW, No. 415, pp. 481-82, 2 June 1494 - but we have no evidence of his having a son called John; the Wylnensis here is merely an hypothesis as is Joannes Grod[n]ensis.

${ }^{61}$ Rosińska, Scientific writings, nos 1174, 177, 373.

${ }^{62}$ Markowski, 'Repertorium bio-bibliographicum', 125. For an excellent account of how these nativitates were drawn up, see Grafton, Cardano's Cosmos, pp. 22-37.

${ }^{63}$ M. Markowski, 'Krakowskie dzieła astronomiczne ważniejsze polonika średniowieczne w rękopisach Biblioteki uniwersyteckiej w Lipsku’, Biuletyn Biblioteki Jagiellońskiej 33 (1984), p. 10, n. 36, quoting Leipzig UL MS 1482, f. 11r-v.

${ }^{64}$ Rosińska, Scientific writings, No. 2344 (BJ Ms. 3225 p. 277-86). 
from the noble Trzecieski family shows the stars of a litigious, proud man. ${ }^{65}$ Horoscopes were cast for various types of tradesman such as a goldsmith, apothecary, merchant or glass maker ${ }^{66}$ as well as for the clergy and nobility. ${ }^{67}$

Historical horoscopes were made to illustrate when certain states formed or expanded their borders. The Hungarians are said to have taken over Pannonia for the second time in March 767 when the sun entered Aries. ${ }^{68}$ Crusade propaganda may have given rise to the making of a horoscope around 1488 connecting the Birth of Our Lord with the rise of the 'Mohammedan Sect' in 571 ( $\mathrm{sic}$ ). A prophecy for the rise of the Turks was held to predict their imminent decline in the $1640 \mathrm{~s}$. It is unclear whether this horoscope was preserved from the fifteenth century or created optimistically in the seventeenth century. ${ }^{69}$ The birth of the city of Venice was also carefully horoscoped as perhaps another encouragement for taking part in a crusade.

Medicine and astrology are spheres where Jewish and gentile practitioners came into contact and competition. We know from other manuscript evidence of contacts and disputes between Jewish and gentile scholars at the court of Casimir IV and his sons. ${ }^{70}$

While birth horoscopes were concocted for members of most social classes, examples from predictions for royalty are our main interest here as part of court culture and propagation of Jagiellonian interests. It is not clear whether these forecasts were drawn up independently from or as a part of the public events they purport to illustrate. ${ }^{71}$ Were astrologers consulted when drawing up the time table for

${ }^{65}$ Stanisław Trzecieski in BJ 3225, pp. 213-228 (Rosińska, Scientific writings, No. 2347).

${ }^{66}$ Rosińska, Scientific writings, Nos 738; 736; 735, 753; 731.

${ }^{67}$ canons: Rosińska, Scientific writings Nos 737, 733, 732.

${ }^{68}$ Rosińska, Scientific writings, No. 730.

${ }^{69}$ Rosińska, Scientific writings, No. 734; seventeenth century finale - Codex epistolaris saeculi decimi quinti, III, ed. A. Lewicki (Cracow, 1894) No. 80 pp. 586-7.

${ }^{70}$ Rosińska, Scientific writings, nos 1120, 1188; on Jewish-gentile disputes at Casimir's court, see Biblioteka Czartoryskich ms. 1399 published in Rowell, 'Fifteenth-century Poland-Lithuania'.

${ }^{71}$ Propaganda for Sigismund the Elder from Joannes Slesita who writes to Aleksander Kruczbarch of the elevation of a fortunate and holy king - felix tamquam sanctus rex de novo exaltaretur, giving tables for Sigismund the Elder's elevation in Vilnius, his birth and his coronation as king (No. 112), cf 728; coronation of Matthias 1464; coronation of Władysław the Jagiellonian as king of Hungary September 18, the twenty second hour, 0 minutes in 1490 - No. 722; birth of Władysław the Jagiellonian: data differ in same manuscript. One table made between 1483 and 1490, the other after 1490 - No. 172, 739; Leonard z 
coronations and battles or did they appropriate public data for their professional purposes? At least where royal births are concerned astrologers seem to have been present at court and to have had to explain their mistakes. The birth charts preserved in BJ 3225 provide a case study.

The manuscript is paper in octavo, from the fifteenth and sixteenth centuries. It presents a collection of various horoscopes made at end of the fifteenth century, copies of earlier manuscript horoscopes, made for use of astrology students in Cracow University. These deal with the stars of Casimir IV and his sons, Matyas Corvin of Hungary, various bishops, the canons of Cracow, magnates, citizenry, and even buildings (St Anne's Church School ${ }^{72}$ ). It is similar to other manuscripts like BJ 3227 and Ossolineum 764 and is probably the same Figurae nativitatum principum listed as having been among Miechowita's books. ${ }^{73}$ Here we will examine horoscopes made for Casimir IV, his coronation and the birth of his first son Władysław.

The information given on the original table seems to be as follows:

Nativitas serenissimi principis Kazimiri Regis Polonie anno 1427 currente ultimo die novembris, tempore inequato 3us post bissextum. D. 29, hr. 20, m. 47, s. 39. Aliqui 29 d., 21 h.. 9 m., 25 sec.

Coronatus est in regem Polonie anno 144724 mensis juniy die Iohannis Baptiste penes horam meridiey. Eodem anno ascendens applicabitur Jovi per corpus ${ }^{74}$. Anno Dni 1453 veniet directio lune ad radium opportunum $\chi^{\nearrow}$ circa inicium octobris.

Anno Dni 1487 circa inicium octobris veniet directio lune ad gradum occidentem.

Anno Dni 1490 nati 63 veniet directio decime ad corpus $\nearrow^{\nearrow}$

Dobczyc prediction for coronation of Jan Olbracht - No. 2350; for children of Casimir Jagiellończyk: 1242 - Alexander; 1244 Frederick, 1245 John Albert; for Hungarian kings: 1246 Janos Corvin, 1249 Matyas Corvin.

72 J. Krukowski, 'Z dziejów budnictwa szkolnego w Krakowie. Budynek szkoły przy kolegiacie św. Anny’, Biuletyn Biblioteki Jagiellońskiej 37 (1987), pp. 85-110 esp. pp. 86-88 and plate 1 between pp. 108-109 showing the horoscope from BJ 3225 p. 230 and the explanation of why the fourth hour after sunrise on July 101510 was chosen for laying the foundation stone. Good times for demolishing buildings could also be foretold, as BJ 764 p. 26 illustrates.

${ }^{73}$ Hajdukiewicz, Biblioteka Macieja, pp. 126-27, 307 No. g.

74 'Quando quis in nativitate habuerat planetas bonas, ut iovem vel solem' speaking of Alexander of Poland-Lithuania, BJ 1923 p. 640; cited Rosińska, Scientific writings, p. 338, No. 1727. 
Anno Dni 1485 Directio medyali id ascendens qui notabile bonum in (mars?) portendit.

Uxorem duxit cum ascendens applicabat ad W. ${ }^{75}$

Around these prognostications another hand has made notes concerning historical events. It seems likely that this commentator was Bernard Wapowski, who names himself in one of the notes:

Ilech et Alkorodon dedit annos nato medios sed 66 sed in 65 obyt in Grodno $^{76}$

1454 in illa illata iam partam victoriam Choynicys a pruthenis paulo ante victoriam obtinuit contra prutenos ${ }^{77}$

1485 Sthephan valachus prestulit omagium in septo ${ }^{78}$

In illis tribus diebus nativitatis precedentis, ante mortem suam apparuerant tres soles in meridie quos ego, Bernardus Vapowski, cantor et canonicus cracoviensis, vidi.

A different hand noted that 'anno 1492 die jovis VI juny mortuus est in Lithuania, Crac[oviam] delatus est'. On the previous page is an inscription in yet another hand (that of Miechowita?) to the effect that:

Obyt autem rex Cazimirus septima Junii, hora quindecima min.46 in Grodno, ductus ante forum Cracovie in decima Julii, absente Alexandro filio eius jam electo in ducem magnum

According to the nineteenth-century doyen of Polish studies of mediaeval astrology, Ludwik Birkenmajer, certain of the marginal notes to Matyas Corvin's birth chart in BJ 3225 p. 8 are 'naiwne'. He notes how the attribution of the king's death (on April 6, 1490) to a conjunction of Saturn and Mars in the sixteenth grade of Capricorn involves the citation of the position of the stars in the second half of December 1489 - a prediction (that was in fact defeat.

${ }^{75}$ Casimir married Elisabeth of Austria in 1454 too, the year of his Choynice

${ }^{76}$ Arabic: haylaj (Latin form, hyleg) or alcohdon, the planet which is dominus vitae - see Tester, History, pp. 169-70.

77 The battle took place on September 17, 1454 - a vague reflection of Dhugosz's comment on how the Poles lost the victory they had first won? Długosz, Hist. V, p. 183.

${ }^{78}$ Stefan of Moldavia swore allegiance to Casimir on September 15 at Kolomyi, for which one of our most extensive sources is Wapowski's own chronicle see F. Papée, Polska i Litwa na przełomie wieków średnich, I: Ostatnie dwunastolecie Kazimierza Jagiellończyka (Cracow, 1904), pp. 199 and 200, n. 2; more recent studies of Moldavian relations with Poland include I. Czamańska, Mołdawia i Wołoszczyzna wobec Polski, Wegier i Turcji w XIV i XV wieku (Poznań, 1996). 
made, according to Bonfini) which is (just) a little wide of the mark, like the calculations of Casimir Jagiellończyk's life expectancy in the text quoted above. ${ }^{79}$ It is unclear whether astrologers counted Casimir's days before his death, an activity that would smack dangerously of imagining the death of the king.

The table on page 2 of the manuscript gives an exact, but incorrect date of June 221447 for Casimir's coronation; strangely the notes on the birth chart also get the date wrong. ${ }^{80}$ In his account of the coronation Długosz notes ominously and without completing his sentence that 'improbabant mathematici multifarie eam coronationem, quod in die execrabili et pessima perfecta sit, et in hora tunc quando ...' ${ }^{81}$ Quite who these astrologers were and who actually consulted them as to which day would be fit for a coronation remains unknown. The various coronation horoscopes may be a post-factum attempt to explain the astrology of the enthronement or, less likely, evidence of pre-coronation planning. The Poznań fire, regarded by some witnesses as a portent of future ill, however, is attributed by Długosz not to the stars but to 'turpissima et sodomitica scelera, quae in curia regia impune committebantur' and the humiliation inflicted by Casimir on his second cousin and rival Mykolas Žygimantaitis. ${ }^{82}$

Such horoscopes were tested by historians; the data given are exact but not necessarily accurate, since times are selected to produce the required result; the information presented by this source is out of line with the claims for astrological prediction made by Długosz - here it is clear that Casimir was born under a lucky star. Similar discrepancies can be found in tables concerning Casimir's son Władysław, king of Bohemia and Hungary which give varying data for his birth.

In conclusion we may say that, while astrologers predicted the conjunctions of the planets and noted what those might mean for life on earth, historians used horoscopes for finding out detailed

${ }^{79}$ L. Birkenmajer, Marcin Bylica, p. 138, n. 198.

${ }^{80}$ Coronatio Regis Polonie anno Domini 1447 in Junio d. 22 h. 23 m. 38; the birth chart gives midday on the feast of St John the Baptist (June 24) The date (June 25) given by Dhugosz is confirmed (should we have cause to doubt the great chronicler?) in a marginal note in BJ 1854, a manuscript of theorica planetarum p. 669: 'dominico die in crastino sancti Johannis Baptiste', Rosińska, Scientific writings, No. 1141 (pp. 227-28).

${ }^{81}$ Dhugosz, Hist. V, p. 33.

${ }^{82}$ Długosz, Hist. V, p. 36. 
data - giving an exact time for births becomes popular in fifteenthand sixteenth-century chronicle writing - and on occasion using the star-gazer's interpretation of such data as part of their own understanding of causation. For their part astrologers used 'history' to 'prove' the accuracy of predictions after the fact, rather as nowadays the vague mumbo-jumbo of Michel de Notre Dame is 'proved' by the man's followers with reference to twentieth century events which Nostrodamus is alleged to have predicted precisely. Consequently historians have a chance to gain 'facts' or 'dates' which they might not otherwise have known about. These two sciences were important in fifteenth-century Poland (and Lithuania) where they were both connected with public life and the royal/ grand-ducal courts.

\section{Author Details}

Professor S. C. Rowell is senior research associate, Lithuanian Institute of History, Vilnius.

Address: Kražiu 5, LT-2001 Vilnius

\section{JOGAILAIČIAI ŽVELGIA ŽVAIGŽDYNUOSNA: ASTROLOGIJOS RĖMĖJAI} XV A. LENKIJOJE-LIETUVOJE

\section{Santrauka}

\section{S. C. ROWELL}

Viduramžiais mokslininkai bandydavo suderinti iš senesnių kartų gautus duomenis bei jų pačių sukauptą empirinę medžiagą su iš anksto sukurtu pasaulio modeliu. Astrologija, kaip kartais suprantama ir dabartiniu jos sekejju, tai istorijos patvirtinimas, naudojant taikomają astronomiją. Neva ižvelgdami ryšius tarp praeities ivvykių bei jų metu stebètos žvaigždžių konsteliacijos, astrologai manė galintys prognozuoti ateities įvykius, laukiant panašios konsteliacijos susidarymo. Savo ruožtu viduramžiu istorikai-metraštininkai, ypač su universitetais susiję mokslininkai, kaip šaltini savo darbui naudojo astrologų tekstus, kuriuose minimi istorijos įvykiai. Tais laikais ir istorikai kartais aiškindavo praeities fenomenus, kuriuos esą veikè žvaigždès. Astrologijos mokslo svarba anglų, prancūzų bei italų valdovų dvaruose nuo seno nemažai tyrinèta, tačiau šioje plotmejje verta neužmiršti bene svarbiausio XV a. astrologijos centro - Krokuvos universiteto. Šiame straipsnyje apžvelgiama astrologijos bei astrologu svarba Jogailaičiu dvaruose bei Jono Długoszo ir kitu istorikų darbuose. 